\title{
The Effects of Problem Solving, Project-Based Learning, Linguistic Intelligence and Critical Thinking on the Students' Report Writing
}

Yusri*

Lecturer in English Study Program, State Polytechnic of Sriwijaya Palembang, Indonesia

Corresponding Author: Yusri, E-mail: yusri@polsri.ac.id

\section{ARTICLE INFO}

Article history

Received: July 07, 2018

Accepted: September 13, 2018

Published: December 28, 2018

Volume: 9 Issue: 6

Advance access: November 2018

Conflicts of interest: None

Funding: None

\section{Key words:}

Problem Solving,

Project Based Learning,

Linguistic Intelligence and Critical

Thinking,

Report Writing

\begin{abstract}
The aim of this research is to know the effects of problem solving, project based learning, linguistic intelligence and critical thinking on the students' report writing. Linguistic intelligence, critical thinking and report writing tests are used to collect the data. Two-factor ANOVA at 0.05 significance level are applied statistically. The findings of this research showed that (1) The students' report writing skill taught through problem solving was higher than those who were taught through project based learning. (2) There were interactions among problem solving, project based learning, linguistic intelligence and critical thinking on the students' report writing. (3) The students' report writing who were taught through problem solving and having high linguistic intelligence and high critical thinking is higher than those who were taught through project based learning and having high linguistic intelligence and high critical thinking (4) The students' report writing skill who were taught through problem solving and having low linguistic intelligence and low critical thinking is lower than those who were taught through project based learning and having low linguistic intelligence and low critical thinking.
\end{abstract}

\section{INTRODUCTION}

The most powerful communication tool is the language. Simply, language can be interpreted as a tool to convey something that comes to mind. However, language is a tool for interacting or communicating tools, in the sense of a tool for conveying thoughts, ideas, concepts or feelings. In education, writing skills have a very important meaning. Students who are not able to write well are likely to face obstacles in communicating, but students who often write, will indirectly hone the ability to think critically in solving all the problems encountered in everyday life. However, many students are unaware of the importance of writing skills. In fact most of them feel lazy and reluctant to write, because in the process of writing needed deep thinking and free time, including writing reports in English.

A person's ability to express ideas is also influenced by linguistic intelligence and critical thinking. In daily activities linguistic intelligence is one of the essential intelligences, because linguistic intelligence is concerned with the ability to write. Linguistic intelligence influences a person's ability to communicate his ideas. It is closely related to language skills, including writing skills. Writing trains students to think critically, to think intelligently and to train them more responsive in dealing with problems. A person who is accustomed to writing will usually be more critical and responsive in the problems he faces. As expressed by Trudell and Mahmuda (2010) that the academic atmosphere in college requires students to think, argue, communicate and continue their learning outside the classroom. The statement indicates that critical thinking ability brings the student to see a problem with a different point of view.

One of the skills that must be mastered by students in the fifth semester after they follow the writing course is the skills of writing reports in English. A report is a form of writing or rhetoric that seeks to explain and describe a subject that can broaden the view or knowledge of a person who reads the description which is primarily intended to tell, peel, decipher or explain something. Based on the observation of the researcher, the problem in writing the report in English to the students of English Department of State Polytechnic of Sriwijaya Palembang namely; (1) Students have problems relating to the inability to express ideas, ideas, illustrations, arguments, reasonable, logical and strong reasons accompanied by examples, or data to strengthen their writing. (2) Students have problems related to linguistic aspects such as: poor word selection or diction, incorrect use of grammar, and the preparation of unfinished paragraphs. 
Learning models applied by researcher to improve skill of writing report in English are problem solving and project based learning. Englander (2002) says that problem solving is the interaction between learners to get the information they want, to reach agreement or solve a problem. It is a learning model where lecturers help students to learn to solve problems through learning experiences (Jacobsen, Eggen, and Kauchak, 2009). It begins with a problem in which the student is responsible for solving it with the help of the lecturer.The second learning model that researcher applied in teaching report writing is project based learning. According to Thomas (2000) project based learning is a model that organizes learning through projects.

\section{RESEARCH OBJECTIVES}

The problem of this study" Were there interaction effects among problem solving, project based learning,linguistic intelligence and critical thinking on students' report writing?" And the aim of this research is to know the effects of problem solving, project based learning, linguistic intelligence and critical thinking on the students' report writing.

\section{LITERATURE REVIEW}

\section{Report Writing}

Keraf (1982) says that the report of one form of writing or rhetoric which seeks to explain and describe a subject that can broaden the view or knowledge of someone who reads the description. Suparno (2006) affirms that the report is essentially the essay to inform, peel, decipher or explain something. And Semi (2007) suggests that the report is 1) some writings that provide understanding and knowledge; 2) It answers questions about what, why, when and so on; 3) It is delivered with open materials;

The structures of writing an English report consists of at least three components:

\section{Thesis}

Thesis is a writer's opinion statement of a particular case or phenomenon. This thesis can also be called issue or matter in question. Issues or thesis we can get from reality or phenomenon can be natural or social phenomenon. The phenomenon that occurs usually cause problems that lead to opinions or opinions that are then presented in the form of text writing that contains an opinion on a particular issue which is then presented in a persuasive with the hope of the reader or listener agree or disagree with the author.

\section{Arguments}

In the paragraph of this argument the author presents the reason why there is concern for an issue over a phenomenon. In his argument the author must present reasons supported by sufficient facts and evidence to convince the reader and may subsequently influence the reader to agree or disagree with the author and accept the advice presented by the author.

\section{Recommendations}

In this paragraph the author presents a statement about suggestions or solicitation of how should or should not something be there or done. The function of this recommendation paragraph is to reinforce the author's opinion by influencing the feelings of the reader or listener and directing them to approve or follow the author's suggestion.

\section{Problem Solving}

Problem solving is a learning model that utilizes the problem as a focal point for the purposes of student investigation and research. This learning model focuses on the role of students or students actively in solving some problems or answering some questions. Carson (2007) says that problem solving as a tool used by individuals uses science, skills, and understanding to solve problems in certain situations. It is said that problem solving is one of the thinking skills that teachers use to teach students to think.

Foshay and Kirley (2003), problem solving is a collection of skills mechanically, systematically and abstractly in problem solving. It often has the correct answers based on logical problem solving with one appropriate answer (a reasonable reason). It is included in high critical thinking skills because students must understand, give reasons, generalize the excavated problems. According to him, problem solving is a basic skill that is needed learners today. There are five stages in this learning model: (1) identifying the problem, (2) defining the problem, (3) exploring the solution (4), executing the strategy and (5) evaluating the strategy.

Doghonadze and Gorhiladze (2008) stated that problem solving uses science and skills to solve unanswered problems or in troubled situations. Furthermore Abed, Davoudi and Hoseinzadeh (2015): 110) said that problem solving is a strategy that must be given to the students so that they can solve problems and get solved from the problem so that they can apply in real life in different situations. Moreover Hussein et al, (2012) stated that roblem solving is a learning model designed with two goals; (1) through a given task, language learning occurs through meaningful interaction with real situations and (2) problem solving works based on the assumption that learning occurs through sharing ideas and knowledge through cooperation in solving problems.

Englander (2002) says that problem solving is the interaction between learners to get the information they want, to reach agreement or solve a problem. There are several stages applied to solve a problem: (1) mentioning problems and choosing one problem, (2) analyzing the problem, (3) brainstorming the solutions, (4) choosing two solutions and (5) Analyzing the solution. According to Jacobsen, Eggen, and Kauchak (2009) problem solving is a learning model where lecturers help students to learn to solve problems through learning experiences. It begins with a problem in which the student is responsible for solving it with the help of the lecturer. It can be concluded that the problem solving is a report writing activity in English involving students in five steps to solve a problem, namely: identifying problems, affirming the problem, choosing a strategy, applying 
the strategy, and evaluating the results supported by ideas, through experience, illustrations, facts, opinions, arguments, reasons, reasonable, logical and strong with the example so as to persuade and influence readers.

\section{Project Based Learning}

Thomas (2000) proposed that project based learning is a model that organizes learning through projects. In the learning process, projects are complex tasks, based on challenging problems or questions, involving students in the design, problem solving, decision making, or investigating activities; giving students opportunities to work within a certain period of time. Project based learning is a student-centered learning model. Then Bas (2011) says in this learning model students plan, implement, and evaluate the tasks assigned to find solutions.

According to Arend (2012) project based learning consists of the results of student presentations resulting from the investigation of a natural and meaningful problem. Then Stoller and Allan (2005) say that project-based learning is learning processes that maximize language, content, meaningful learning, require a combination of teacher roles, reciprocal feedback from lecturers, student agreements, with challenging tasks. Hunt and Beglar (2003) argue that project based learning is also a project that wants learners in groups of two to four people and choose a topic that they are interested in or want to find a solution.

Then Thitivesa (2014) interprete that project based learning is a learning model that integrates between language and the content of language learning goals. This lesson conditioned learning with problems to solve. From the terms, the researcher uses the term project based learning in this study. The author refers to what the Tesemma (2005) said. Project based learning is a writing assignment given to students to write a short essay in three steps, namely: illustrating problems, identifying problems and proposing a solution to the problem. Activities take place inside and outside and students work individually, in groups and in pairs. It can be concluded that project based learning is an activity that involves students in groups to write report writing in English in three steps, namely: describe the problem, identify problems and propose solutions to the problem with the idea, experience, illustrations, facts, opinions, arguments, excuses, reasonable, logical and powerful with examples so as to persuade and influence readers.

\section{Linguistic Intelligence}

A person's ability to express ideas is also influenced by the level of intelligence, one of which is linguistic intelligence. In daily activities linguistic intelligence is one of the essential intelligences, because linguistic intelligence is concerned with the ability to write. Linguistic intelligence influences a person's ability to communicate his ideas. Students who have good linguistic intelligence, then they will be able to communicate with others both orally and non-verbally.

Ahmed (2102) says that linguistic intelligence involves language both orally and in writing. According to him, It is the ability to learn the language and use the language to achieve certain goals. This intelligence includes the capacity of a person to use language effectively to express something to others, including expressing something in writing. Then Swasti, M. Candiasa, W.S Warpala (2013) argue that linguistic intelligence is an individual's ability that involves sensitivity to spoken and written language, the ability of language to learn the language, and the ability to use language to achieve certain goals. Nima, Reihaneh and Morteza (2017) say that inguistic intelligence includes the ability to convince others using words, using creative writing skills, and the ability to absorb other languages easily. According to Vincey and Pugalenthi (2016) linguistic intelligence is the ability to think words and use them to convey messages to others. When someone holds a conversation with another person, that person uses their linguistic intelligence.

Then Hoekstra-Roos (2010), linguistic intelligence is intelligence in language and communication. This intelligence includes the ability to speak, express and convince thoughts and feelings to the outside world in one or more languages. This intelligence can be in written and oral form. This intelligence includes the ability to hear and understand others. He thinks children with high linguistic intelligence are easily recognizable. The children love to talk, love to read and write and never complain about writing.

Furthermore, linguistic intelligence is the ability to use words effectively or matters related to sensitivity to words and wording. Armstrong (2009. Finally Nelson (1998) says that he linguistic intelligence of a person's ability to use language and sensitive to nuance, sequence, rhythm of words. It can be concluded that linguistic intelligence is the ability of a person in using the language both orally and in writing, including rhetorika (ability to influence others), mnemonic (Ability to remember something), eksplanation (Use of language to provide information), and metalinguistics (Language use to discuss the language itself).

\section{Critical Thinking}

Developing critical thinking skills in the curriculum helps strengthen educated citizens, prepares students for college, promotes future careers, and social life (Stobaugh, 2013: 4). According to Hunter (2014: 2) critical thinking is a reasonable or logical reflective way of thinking to determine what to do and believe. Then Starkey (2004) says critical thinking is generally closely related to two things: problem solving and reasoning. Critical thinking is related to the ability to (2) make observations, (2) curiosity, provide relevant questions and find needed resources, (3) identify and define problems, (4) evaluate the validity of statements and arguments, (5) make wise decisions and get a valid settlement, (6) understand reasonable arguments. Another opinion about critical thinking is proposed by Ruggiero (2011 critical thinking is a conscious mental process used to solve problems, make decisions, or gain understanding.) Then according to Lau (2011: 1) critical thinking is to think clearly and enter Critical thinking is concerned with thinking appropriately and systematically or structured, and following logical rules and scientific reasons. 
Stobaugh (2013) argues that ritical thinking is an in-depth science process for identifying problem relationships and finding pontential creative solutions to solve them. In this case critical thinkers use reflective decisions and seek problem solving to analyze situations, evaluate arguments and describe appropriate inferences. Critical thinking is to consider ideas, evaluate those opinions that have been understood and make decisions about the benefits of those ideas. Based on the above description, it can be concluded that critical thinking is the ability to think directly on a problem, analyze, solve the problem, conclude and then evaluate it.

\section{RESEARCH METHODOLOGY}

The method used in this research is the experimental method with the design of treatment design by level $2 \times 2$. The population is 80 students, the fifth semester students, the English Department at the Politeknik Negeri Sriwijaya Palembang. The sample in this research is done by using multistage random sampling technique. Data were obtained in three ways by giving linguistic questionnaire, critical thinking test and writing test. The validity of the content of a report writing skill is determined by first defining the assessment criteria. This criterion is formulated based on theories presented by the expert. To see the reliability of the instrument of report writing is done with the reliability of the interrater (interrater reliability). The questionnaire assessment (quesioner) of linguistic intelligence in general according to experts can be used to measure students' linguistic intelligence. In this study, the writer used instrument designed by Wiwitan (2013: 43-45). To measure the critical ability of critical thinking, researchers used the critical thinking assessment instrument "Watson Critical Thinking Apraisal Practice Test (Watson \& Glaser, 2002). The critical thinking skills test consists of 17 questions in Multiple Choice that measure the ability to make inferences, recognizing assumptions/Recognizing assumptions, Deduction, Interpretation, Evaluation of Arguments.

Statistical analysis to test using technique of variance analysis (Anava) two lane with $F$ test at significance 0,05 . If
F test is critically significant, there is an interaction among problem solving, project based learning,linguistic intelligence, and critical thinking to students' report writing, then the test is continued with Tukey test.

\section{DISCUSSION AND ANALYSIS}

\section{Data Description}

The purpose of describing the data of this study to describe the skills of writing reports, the fifth semester students, English Department in the academic year of 2017-2018 by applying problem solving and project based learning. The scores of the students' report writing are divided into eight groups based on problem solving and project based learning as well as the linguistic intelligence (high and low), and critical thinking (high and low).

Table 1 summarizes the scores of the students' report writing skills of the entire data group in this study.

\section{Hypothesis Testing}

Hypothesis testing in this research has been done by using two-factor ANAVA and continued with Tukey test, if there is interaction in test, two path anaysis variance is used to examine the main effects and interaction effects among problem solving, project based learning, linguistic intelligence, and critical thinking on students' report writing.

\section{First Hypothesis}

The results of two-factor ANAVA between the columns in the variance analysis table show: $F$ count $=6.52$ is higher than F_tabel $=4.11$ at significance level $\alpha=0.05$. This means H_0 is rejected and accepts H_1. This proves that there is a significant difference between the students who learn through problem solving (A1) with the group of students who learn through project based learning (A2) on the students' report writing.

Table 1. Summary of students' report writing

\begin{tabular}{|c|c|c|c|c|c|}
\hline \multirow[t]{2}{*}{ Data group } & \multicolumn{5}{|c|}{ Statistic data } \\
\hline & $\begin{array}{l}\text { The total } \\
\text { of the data }\end{array}$ & $\begin{array}{l}\text { Highest } \\
\text { score }\end{array}$ & $\begin{array}{l}\text { Lowest } \\
\text { score }\end{array}$ & Mean & $\begin{array}{l}\text { Standar } \\
\text { deviation }\end{array}$ \\
\hline Problem solving (A1) & 20 & 67 & 85 & 77,60 & 6,02 \\
\hline Project based learning (A2) & 20 & 65 & 82 & 75,25 & 4,40 \\
\hline High linguistics intelligence and high critical thinking (B1) & 20 & 65 & 85 & 77,40 & 6,18 \\
\hline Low lingustic intelligence and low critical thinking (B2) & 20 & 67 & 82 & 74,45 & 4,29 \\
\hline $\begin{array}{l}\text { Problem solving, high linguistic intelligence, high critical } \\
\text { thinking (A1B1) }\end{array}$ & 10 & 80 & 85 & 82,80 & 1,76 \\
\hline $\begin{array}{l}\text { Project based learning, high critical thinking and high linguistic } \\
\text { intelligence (A2B1) }\end{array}$ & 10 & 65 & 76 & 72,00 & 3,56 \\
\hline $\begin{array}{l}\text { Problem solving, low linguistic intelligence, and low critical } \\
\text { thinking (A1B2) }\end{array}$ & 10 & 67 & 78 & 72,40 & 3,65 \\
\hline $\begin{array}{l}\text { Project based learning, low linguistic intelligence, and low } \\
\text { critical thinking (A2B2) }\end{array}$ & 10 & 75 & 82 & 78,50 & 2,16 \\
\hline
\end{tabular}




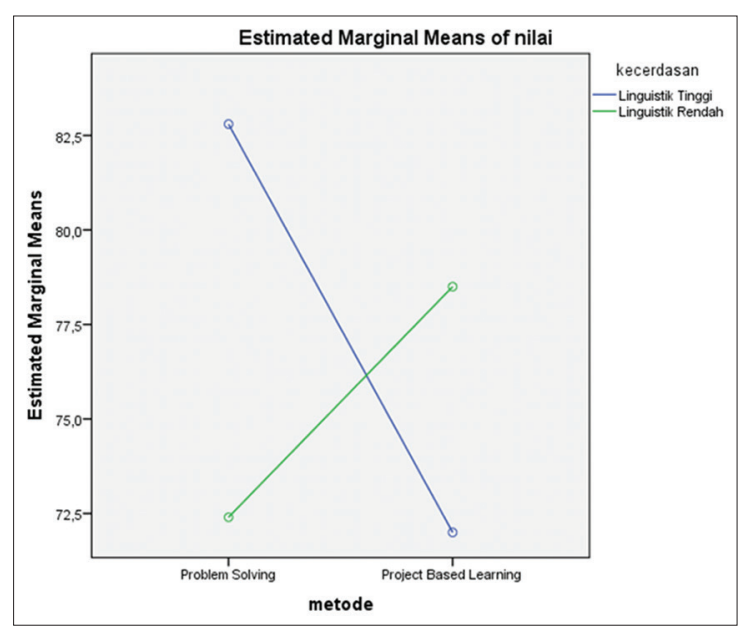

Visualizing the interaction between the learning model and linguistic intelligence in its influence on the students' report writing

\section{Second Hypothesis}

Based on result of two-factor ANAVA between columns and rows in variance analysis table show $\mathrm{F}$ _count $=84,40$ is higher than F_tabel $=4,11$ at significance level $\alpha=0,05$. This means $H_{-} 0$ is rejected and accepts $H_{-}$1. This proves that there is an interaction effect between problem solving and project based learning and the linguistic intelligence (high and low) on the students' report writing.

\section{Third Hypothesis}

Based on the result of further test using tukey test in tukey table shows $\mathrm{Q}$ account $=11,74$ is higher than $\mathrm{Q}$ table $=3,96$ at significance level $\alpha=0,05$. This means H_0 is rejected and accepts H_1. This proves that students' report writing to students who learnt through problem solving and have high linguistic intelligence and high critical thinking is higher significantly than students who learnt through project based learning. Thus there is a significant difference.

\section{Fourth Hypothesis}

Based on the results of further tests using tukey test on the tukey table shows $Q$ accoun $=6.63$ is higher than Q tabel $=3.96$ at significance level $\alpha=0.05$. This means that H_0 rejected and accept H_1.Hal this proves that the students' report writing learn through problem solving and have low linguistic intelligence and low critical thinking lower significantly compared with students who learn through project based learning. Thus there is a significant difference.

\section{DISCUSSION}

Through descriptive analysis obtained the average score of the students' report writing students who were taught through problem solving and project based learning that is 77.15 and 75,15 . This fact is supported by the results of inferential analysis which states that there is a significant difference between the learning with the problem solving and project based learning.
Students who have high linguistic intelligence and high critical thinking, through descriptive analysis gives the difference between the average score of report writing between students who learn through problem solving and students who study with project based learning. The average score is 82.80 and 72.00. These average scores give a considerable margin. So descriptively it can be said both are different. The result of hypothesis testing is that there is a significant difference between the students' report writing who have high linguistic intelligence and high critical thinking who learn with the problem solving with project based learning. With these facts, it is said that for students who have high linguistic intelligence and high critical thinking, the problem solving is better than project based learning in the skills of report writing.

Students who have low linguistic intelligence and low critical thinking, through descriptive analysis gives the difference between the average score of report writing between students who are learning with the problem solving and students who study with project based learning. The average score is 72.40 and 78.50. Both these average scores give a considerable margin. So descriptively it can be said both are different. The result of hypothesis testing is that there is a significant difference between the skill of writing the report in the English language students who have low linguistic intelligence and low critical thinking who learn with the problem solving with project based learning. With these facts, it is said that for students who have low linguistic intelligence, project based learning is better than the problem solving learning in student report writing skills. The interaction between problem solving and project based learning applied to improve the skill of writing the report in the English language of students is shown by the result of hypothesis testing where it was decided to reject $\mathrm{H}_{-} 0$ at the level of significance $\alpha=0.05$ which means a significant influence on the effectiveness of the problem solving and project based learning in improving the skills of report writing in English students in this research.

From all analysis result which have been described both with descriptive analysis and with inferential analysis, it is reasonable to say that the use of problem solving is better in improving students' report writing that have high linguistic intelligence and high critical thinking, while project based learning is not more better than the problem solving in improving the skills to write reports for those who have high linguistic intelligence and high critical thinking.

\section{CONCLUSION}

Based on the findings of this study, it can be concluded that the application of learning models; problem solving and project based learning in accordance with linguistic intelligence and critical thinking of students can effect students' report writing. Students who were taught through problem solving with high linguistic intelligence and high critical thinking can effect students' report writing. On the other hand, students who were taught through project based learning with low linguistic intelligence and low critical thinking 
can influence students' report writing. So, both the learning model; problem solving and project based learning, linguistic intelligence and critical thinking influence students' report writing.

\section{REFERENCES}

Ahmed Alseed Gasm Ahmed. The Relationship between Multiple Intelligences and Methods of ELT. International Journal of Learning and Teaching. Vol 4, Issue 2012.

Arends, R.I. Learning to Teach, $9^{\text {th }}$ ed. Boston: McGraw Hill Company Inc, 2012.

Armstrong Thomas. Multiple Intelligence in the Classroom. ASCD: Alexandria, Virginia, 2009.

Bas Gokhan. Investigating the Effects of Project Based Learning on Students' Academic Achievement and Attitudes towards English Lesson. TOJNED. The Online Journal of New Horizons in Education-October, volume 1, issue 4, 2011.

Carson Jamin. A Problem with Problem Solving Teaching Thinking without Teaching Knowledge. The Mathematics Educator, Vol 17, No 2, 7-14, 2007.

Doghonadze Natela and Gorhiladze Gulnara. Problem Solving in Teaching Foreign Languages to Students of Pedagogical Departments. IBSU Scientific Journal Vol 2 (1), 2008.

Englander Karen. Real Life Problem Solving: A Collaborative Learning Activity. English Teaching Forum. January, 2002.

Glaser Edwin-Watson Good Win: Watson Glaser Critical Thinking Appraisal-UK Edition.England: Pearson Assesment, 2002.

Hoseinzadeh Davoud, Davoudi Mohammad Hosein Amir and Abed Soheila. The Effect of Synectics Pattern on Increasing the Level of Problem Solving and Critical Thinking Skills in Students of Alborz Province. WALIA Journal 31:110-118, 2015.

Hunt Alan and Beglar David. Edited by Richards and Renandya. Methodology In Language Teaching: An Anthology of Current Practice: Implementing Task Based Language Teaching. Cambridge: Cambridge University Press, 2003.

Hunter, David A. A Practical Guide to Critical Thinking: Deciding what to and believe. Second Edition. Toronto, ON, Canada: Willey, 2014.

Hussein Hawanum and Abdullah Maria Chong, Noordin Nooren and Roslan Samsilah. Using the Problem Solving to teach Writing to EFL Learners. The English Teacher Vol. XI.1 (2) December 2012.

Kauchak D, Egen P and Jacobsen A David. Methods for Teaching: Metode-Metode Pengajaran Meningkatkan Belajar Siswa TK-SMA. Indonesia: PustakaPelajar, 2009.

Keraf, Gorys. EksposisidanDeskripsi. EndeFlores: Nusa Indah, 1982.

Kirkley Jamie and Foshay Rob. Principles for Teaching Problem Solving. Plato Learning Inc,:2003.

Krajcik, Marx, Ronald, Soloway Blumenfeld and Phyllis. Motivating Project Based Learning: Sustaining the
Doing, Supporting the Learning. Educational Psychologist, 26 (3\&4), 369-398, 1991.

Nelson Nicholson Kristen. Develoving Students' Multiple Intelligences. Scholastic Inc: New York, NY, 1998.

Nima, Reihaneh and Morteza. On the Relationship between Linguistic Intelligence and Recalling Lexical Items in SLA. International Journal of Research Studies in Education. Volume 6, Number 4, 2017.

Roos and Hoekstra. Linguistic Intelligence. International Montessori Schools and Child Development Centres: Brussels, Belgium, 2010.

Ruggiero Ryan Vincent. Beyond Feelings: A Guide to Critical Thinking. McGraw-Hill: New York, 2011.

Semi, Atar. Dasar-DasarKeterampilanMenulis. Bandung Angkasa, 2007.

Starkey Lauren. Critical Thinking Skills Success in 20 Minutes a Day. Learning Express, LLC: New York, 2004.

Stobaugh Rebecca. Assessing Critical Thinking in Middle and High Schools: Meeting the Common Core. Routledge: new York, 2013.

Stoller L and Allan B. 2005. Maximizing the Benefits of the Project Work in Foreign Language Classrooms. English Teaching Forum. 43 (4), 2005.

Suparno. 2006. KeterampilanDasarMenulis. Jakarta: Depdikbud UT.

Thitivesa Duangkamol. The Academic Achievement of Writing via Project Based Learning. International Journal of Social, Behavioral, Education, Economic, Business and Industrial Engineering, Vol 8 No 9, 2014.

Tessema Assefa Kedir. Stimulating writing through project-based tasks. English Teaching Forum. 42 (4), 2005.

Thomas, W. John. A Review of Research on Project-Based Learning. California: The Autodesks Foundation 111 Melnnis Parkway, 2000.

Trudell Beth and Shaila Yasmin Mahmuda. From Passive learners to Critical Thinkers: Preparing EFL Students for University Students. English Teaching Forum, 48 (3), 2010.

Vincey D and Pugalenthi N. A Study of Linguistic Intelligent and Academic Achievement of the Students at Standard IX Level. Shanlax International Journal of Education. ISSN:2320-2653. Vol 4 No 2, 2016.

Warpala, s. Candiasa and Swasti. Pengaruh Model Pembelajaran Kontekstual dan Kecerdasan Linguistik terhadap Keterampilan Menulis dalam dalam Bahasa Inggris di Kelas X di SMK Negeri 1 Abang. E-Journal Program Pascasarjana Universitas Pendidikan GAnesha Program Studi Teknologi Pendidikan. Vol 3, 2013.

Weigle Cushing Sara. Assessing Writing. Cambridge University Press: United Kingdom. 2009.

Whitfield Merryn. NAPLAN* Persuasive Text: Sample Work Sheets-Primary. Blake Education: Sydney. 2010.

Wiwitan Khairani Anggit. Hubungan Kecerdasan Linguistik dengan Hasil Pembelajaran Menulis Karangan Narasi Siswa Kelas X SMK Negeri 12 Bandung. Universitas Pendidikan Indonesia |Repository.upi.edu|perpustakaan. upi.edu.2013. 